\title{
CHANGES IN GUT GROSS MORPHOLOGY OF TRAÍRA, Hoplias malabaricus (TELEOSTEI, ERYTHRINIDAE) DURING LONG-TERM STARVATION AND AFTER REFEEDING
}

\author{
RIOS, F. S., ${ }^{1}$ KALININ, A. L., ${ }^{2}$ FERNANDES, M. N. ${ }^{2}$ and RANTIN, F. T. ${ }^{2}$ \\ ${ }^{1}$ Departamento de Biologia Celular, Universidade Federal do Paraná, C.P. 19031, \\ CEP 81531-970, Curitiba, PR, Brazil \\ ${ }^{2}$ Departamento de Ciências Fisiológicas, Universidade Federal de São Carlos, Via Washington Luís, \\ km 235, CEP 13565-905, São Carlos, SP, Brazil \\ Correspondence to: Francisco Tadeu Rantin, Departamento de Ciências Fisiológicas, Universidade Federal de São \\ Carlos, CEP 13565-905, São Carlos, SP, Brasil, e-mail: ftrantin@power.ufscar.br \\ Received November 12, 2002 - Accepted April 3, 2003 - Distributed August 31, 2004
}

(With 2 figures)

\begin{abstract}
Adult traíra (Hoplias malabaricus) were submitted to different periods of food deprivation (from 30 to 240 days) and refed for 30 days after 90 and 240 days of starvation. Stomach length remained constant during all the experimental period. However, the intestine length was significantly reduced after 30 days of food deprivation. Normal length was not recovered after refeeding. The number of pyloric caeca did not change significantly. Conversely, caeca thickness decreased after 150 days of starvation and their length decreased after 180 days. After refeeding, however, the pyloric caeca recovered original thickness. In fish refed after 240 days of starvation the length of these structures seemed to present compensatory growth, becoming longer than in the control group.
\end{abstract}

Key words: gut, gross morphology, pyloric caeca, starvation, refeeding.

\section{RESUMO}

\section{Alterações na morfologia do trato digestório da traíra, Hoplias malabaricus (Teleostei, Erythrinidae), durante jejum prolongado e realimentação}

Traíras (Hoplias malabaricus) adultas foram submetidas a diferentes períodos de privação de alimento (de 30 a 240 dias) e realimentadas por 30 dias após 90 e 240 dias de jejum. O comprimento do estômago permaneceu constante durante todo o tempo experimental. No entanto, o comprimento do intestino reduziu significativamente após 30 dias de jejum. O comprimento normal não foi recuperado após a realimentação. O número de cecos pilóricos não sofreu modificações significativas. Por outro lado, a espessura dos cecos diminuiu após 150 dias de privação de alimento e seu comprimento diminuiu após 180 dias. Após a realimentação, porém, os cecos pilóricos recuperaram a espessura original. Nos peixes realimentados após 240 dias de jejum, os comprimentos dessas estruturas aparentemente apresentaram crescimento compensatório, tornando-se mais longas que as do grupo controle.

Palavras-chave: trato digestório, morfologia, cecos pilóricos, privação de alimento, realimentação.

\section{INTRODUCTION}

Buddington et al. (1997) revised the structure and function of the intestine of carnivore fish and observed a relationship between the diversity of functional demands placed on an organ system and the variation of structure. Correspondingly, of all vertebrate organ systems, the gastrointestinal tract and respiratory system are structurally the most variable. The expansive surface area of the intestine represents a selectively permeable barrier that allows nutrient absorption, but excludes most toxic subs- 
tances and pathogenic organisms. Additionally, the intestin presents three other important functions: water and electrolyte balance, immunity, and regulation of digestion and metabolism. Intestinal structure can respond rapidly and reversibly to changes in dietary inputs, and is of critical interest to ecologists and importance to culturists.

Pyloric caeca are blind diverticula of the proximal intestine found in many fishes, but their function is unclear. Based largely on structure, several authors (Dawes, 1929; Jansson \& Olsson, 1960; Buddington \& Diamond, 1986) have suggested that their function is not basically different from that of the proximal intestine. Histologically, they are similar to the intestine, presenting a number of folds and furrows, which increase the absorptive and secretory surface and work as a food reservoir (Williams \& Nickol, 1989; Zavala-Camin, 1996; Buddington et al., 1997; Kubitza, 1999). In salmonids, the proximal intestine and its associated caeca are the major site for absorption of lipids (Ostos Garrido et al., 1993) and carotenoids (Guillou et al., 1992). Furthermore, taking into account the position of the pyloric caeca and their absence in stomachless fishes, it is possible that one of the roles of these structures is to increase the bolus $\mathrm{pH}$, optimizing digestion in the anterior portion of the intestine (Zavala-Camin, 1996).

It is well known that gut length is closely related to the properties of food consumed by fish. As an example, phytophagous and detritivore species present longer guts when compared to carnivores, allowing the consumption of food with low digestibility (e.g., Gerking, 1994). Shorter digestive tracts, as observed in carnivores, present a greater number of villi and pyloric caeca, which amplify manifold and compensate for a relatively short intestine (Buddington et al., 1997; Kubitza, 1999).

In several studies (O'Connell, 1976; Ehrlich et al., 1976; Theilacker, 1978; Yin \& Blaxter, 1986; Segner et al., 1987; Uriarte \& Balbontín, 1987), gut morphology was used as a clue to larvae condition during the transition phase from endogenous to exogenous feeding, when the larvae often experience a critical period of starvation. The digestive tract and its associated glands are the first organs impaired by food deprivation (Theilacker, 1978). In adult fish, starvation can produce degeneration and atrophy of a number of digestive tract structures (Love, 1970, 1980; Noaillac-Depeyre \& Gas, 1974; Gas \& Noaillac-Depeyre, 1976; Peters, 1982; Kuperman
\& Kuz'mina, 1994; Collins \& Anderson, 1995; Hall \& Bellwood, 1995; Baeverfjord \& Krogdahl, 1996).

The morphology of the oro-pharyngeal cavity of traíra, Hoplias malabaricus, indicates its ability to swallow whole preys, especially nektonic organisms (Menin \& Mimura, 1991). The gut length/ total body length ratio (gut quotient) characterizes traíra as an essentially piscivorore species (Barbieri et al., 1994), which is corroborated by studies on its feeding habits (Knöppel, 1970; Paiva, 1974, Caramaschi, 1979; Bistoni et al., 1995). However, during annual drought periods, this species usually overcomes severe food scarcity (Lowe-McConnell, 1975). Some authors have found that traíra presents great tolerance to food deprivation (Paiva, 1974; Machado et al., 1989; Rios et al., 2002). However, studies on morphological changes induced by starvation are lacking for this species.

The main purpose of the present study was to evaluate the effects of long periods of food deprivation, and subsequent refeeding, on the gut length, and number and dimensions of pyloric caeca.

\section{MATERIAL AND METHODS}

\section{Experimental animals}

Adult specimens of $H$. malabaricus $(251.7 \pm$ $6.5 \mathrm{~g}$ ) were collected in the Mogi-Guaçu River basin (near São Carlos, SP, Brazil). The fish were maintained for at least 3 weeks in $500 \mathrm{~L}$ tanks supplied with a continuous flow of normoxic water, at constant temperature $\left(25 \pm 1^{\circ} \mathrm{C}\right)$ and $12 / 12$ photoperiod.

\section{Feeding treatment}

During the acclimation period, traíras were fed weekly on small live fish (Astyanax, Prochilodus, Geophagus, and Oreochromis) of a size appropriate for being completely swallowed. After acclimation, fish received the same type of food, but at controlled levels ( $2 \%$ of biomass . day ${ }^{-1}$ ) during 30 consecutive days. The control group was sampled just after this feeding period. Eight groups of 10 individuals were subjected to $30,60,90,150,180$, and 240 days of food deprivation. Two groups were kept under starvation for 90 days and two groups for 240 days, and one of each of these latter was refed for 30 days after the starvation period $\left(2 \%\right.$ of biomass . day $\left.{ }^{-1}\right)$.

\section{Gut sampling and morphometry}

Fish were sacrificed by rapid decapitation, weighed, and measured for the following: (1) gut 
length (from cardic sphincter to anus), (2) stomach length (from the cardic to the pyloric sphincter), and (3) intestine length (from the pyloric sphincter to the anus). Organ lengths were expressed as a ratio of standard length $\left(\mathrm{L}_{\mathrm{S}}\right.$; distance from the edge of the snout to the end of the caudal peduncle) and not of total length $\left(\mathrm{L}_{\mathrm{T}}\right)$, as done, e.g., by Barbieri et al. (1994), since traíra caudal fin are often impaired. The ratios are dimensionless and named as: gut quotient $\left(\mathrm{Q}_{\mathrm{G}}-\right.$ gut length $\left./ \mathrm{L}_{\mathrm{S}}\right)$, stomach quotient $\left(\mathrm{Q}_{\mathrm{S}}\right.$ stomach length/ $\left.\mathrm{L}_{\mathrm{S}}\right)$, and intestine quotient $\left(\mathrm{Q}_{\mathrm{I}}-\right.$ intestine length $/ \mathrm{L}_{\mathrm{S}}$ ).

The digestive tracts were fixed in $10 \%$ formaline. The number, length, and thickness (external diameter at the base) of pyloric caeca were obtained under a stereoscopic microscope (Zeiss Stemi SV6 with a millimetric scale in one of the ocular lenses). About $50 \%$ of randomly chosen caeca were used to measure their size. Length and thickness of pyloric caeca were expressed as a percentage of $\mathrm{L}_{\mathrm{S}}$.

\section{Statistics}

One-way analysis of variance (ANOVA), complemented by Bartlett's test for homogeneity of variances and the Tukey-Kramer multiple comparisons test, were employed to analyze the data of each group (GraphPad Instat - GraphPad Software Version 3.0). Data were expressed as mean \pm SEM and considered significantly different when $\mathrm{p}<0.05$.

\section{RESULTS}

After 30 days of starvation, total gut quotient $\left(\mathrm{Q}_{\mathrm{G}}\right)$ decreased about $31 \%(\mathrm{p}<0.001$; Fig. 1). The same tendency was observed for the intestine quotient $\left(\mathrm{Q}_{\mathrm{I}}\right)$, which decreased about 33\% ( $<0.001$; Fig. 1). The size of these structures remained reduced during the longer periods of food deprivation. Refed fish did not recover the gut and intestine lengths. Stomach quotient $\left(\mathrm{Q}_{\mathrm{S}}\right)$ did not change significantly during starvation and refeeding (Fig. 1).

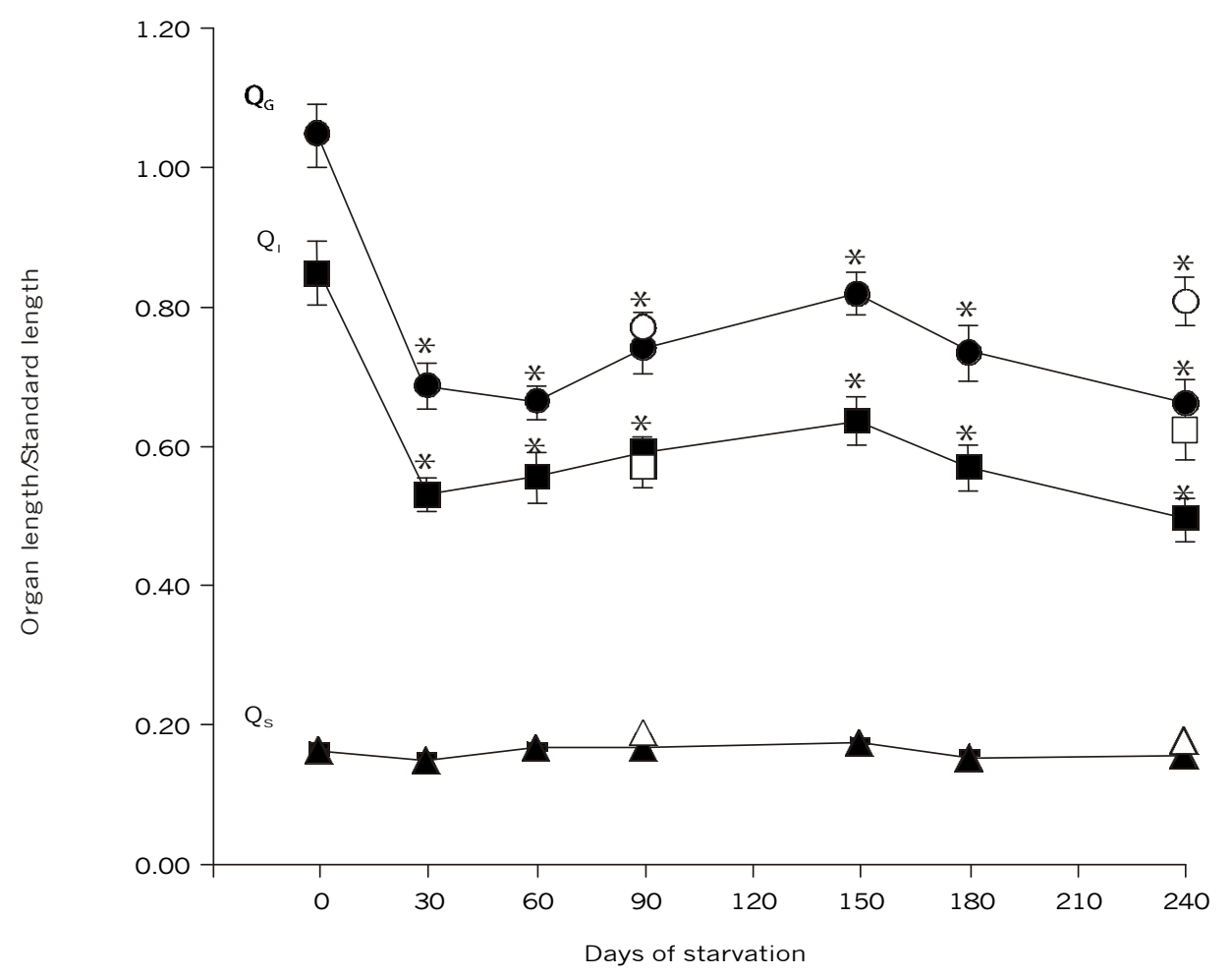

Fig. 1 - Relative length of the gut of traíra, H. malabaricus, in relation to days of starvation. Symbols: - Gut quotient $\left(\mathrm{Q}_{\mathrm{G}}\right)$, $\mathbf{\square}$ - Intestine quotient $\left(\mathrm{Q}_{\mathrm{I}}\right)$, and $\boldsymbol{\Delta}$ - Stomach quotient $\left(\mathrm{Q}_{\mathrm{S}}\right)$ after each starvation period; $\mathrm{O}$ - Gut quotient $\left(\mathrm{Q}_{\mathrm{G}}\right), \square-$ Intestine quotient $\left(\mathrm{Q}_{\mathrm{I}}\right)$, and $\triangle-$ Stomach quotient $\left(\mathrm{Q}_{\mathrm{S}}\right)$ of fish refed after 90 and 240 days of starvation. Statistics: $*-$ significant difference in relation to the control values $(\mathrm{p}<0.001)$. Values are mean $\pm \mathrm{SEM} ; \mathrm{n}=10$. 
The number of pyloric caeca remained constant during all periods of food deprivation $(95.9 \pm 3.3)$. However, pyloric caeca thickness decreased gradually, becoming significantly reduced (about 29\%) after 150 days of starvation ( $\mathrm{p}<0.001$; Fig. 2A) as was caeca length (about 20\%) after 180 days of starvation ( $p<0.001$; Fig. 2B). In the refed fish, the caeca recovered original thickness and length. In fish refed after 240 days of starvation, the length of these structures actually became significantly longer (about 23\%; $\mathrm{p}<0.001$ ) than in the control group.
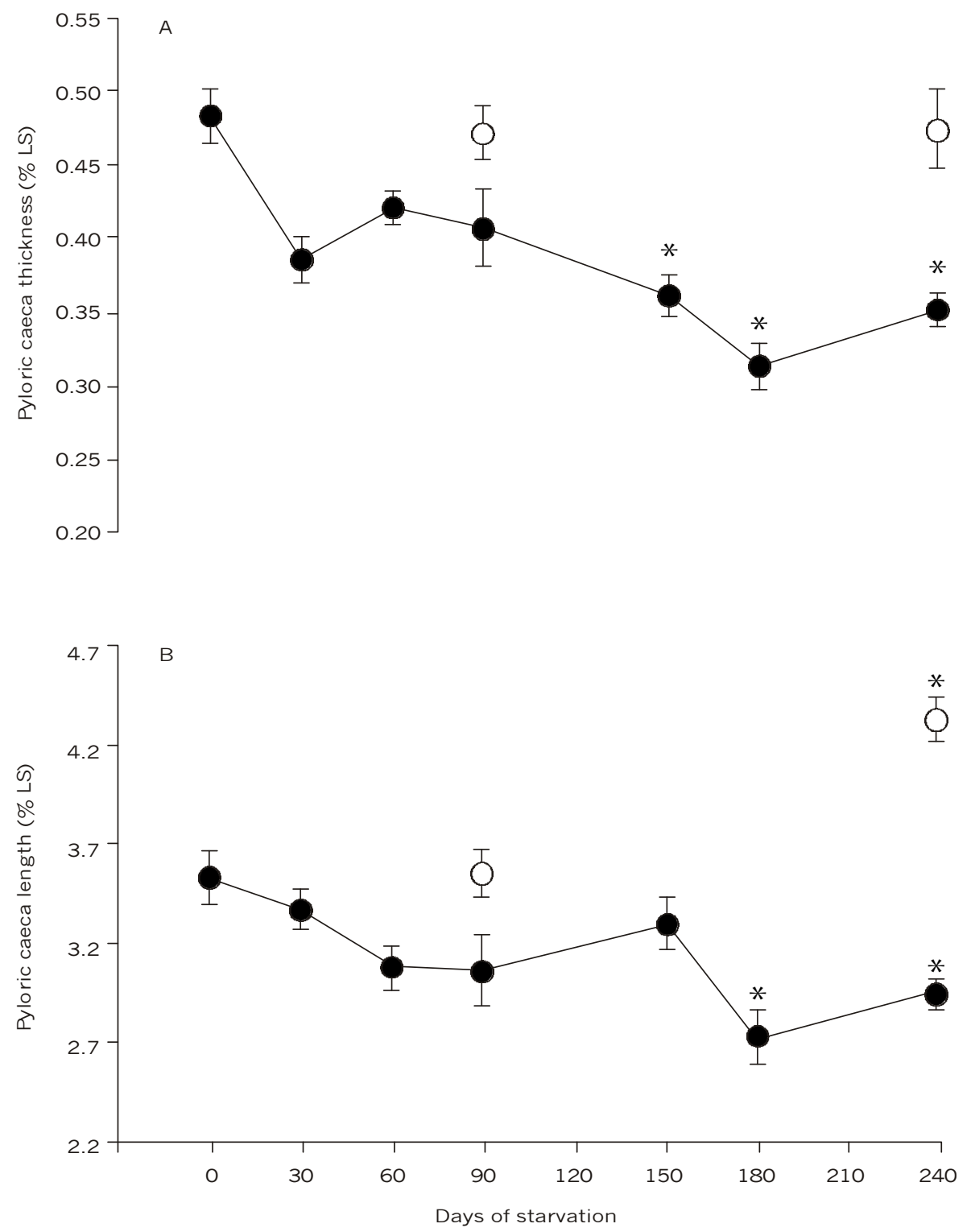

Fig. 2 - (A) Pyloric caeca thickness and (B) length of traíra, H. malabaricus, in relation to days of starvation. Symbols: after each starvation period and $\mathrm{O}$ - fish refed after 90 and 240 days of starvation. Statistics: $*$ - significant difference in relation to the control values $(\mathrm{p}<0.01)$. Values are mean \pm SEM; $\mathrm{n}=10$. 


\section{DISCUSSION}

Some authors believe that reduced nutrient concentration in the gut lumen as well as lack of direct stimulation by food are partially responsible for mucosal atrophy (McLesse \& Moon, 1989). Gut mucosa seems to be extremely dynamic and to respond very quickly to food availability. The larvae midgut of some fish species is extremely vulnerable to food deficiency of food, usually presenting changes after 1 day of starvation (Theilacker, 1978).

Since stomach length did not present changes related to food deprivation, gut length variation could be attributed to intestinal length decrease. Reductions in gut weight, length, or diameter are often observed in fish chronically deprived of food (Angelescu \& Gneri, 1949; Gas \& Noaillac-Depeyre, 1976; Love, 1980; Kuperman \& Kuz'mina, 1994; Collins \& Anderson, 1995; Baeverfjord \& Krogdahl, 1996).

A number of histopathological and ultrastructural changes were verified in the gut of fish subjected to periods of starvation. Absorptive surface reductions by regression or distortion of villi or microvilli (Gas \& Noaillac-Depeyre, 1976; Segner et al., 1987; Hall \& Bellwood, 1995) or mucosal thickness reductions due to decreased heights of epithelial cells (Hall \& Bellwood, 1995) were observed in different species. There have also been noted in starved fish a widening of intercellular spaces and loosening of cell contacts (O'Connell, 1976; Theilacker, 1978; Peters, 1982; Nonotte et al., 1986; Segner et al., 1987); cell dissociation and disruption in mucosa (Uriarte \& Balbotín, 1987); swelling of mitochondria and dilation of reticular system (Gas \& NoaillacDepeyre, 1976; Peters, 1982; Somasundaram et al., 1985; Segner et al., 1987); vacuolization (Peters, 1982; Eckmann, 1985; Segner et al., 1987); an autophagic process (Gas \& Noaillac-Depeyre, 1976; Peters, 1982; Segner et al., 1987); size reduction and disappearance of supranuclear vacuole and decrease in number of microvillous invaginations (O'Connell, 1976; Theilacker, 1978; Iida \& Yamamoto, 1984; Segner et al., 1987).

Gut epithelium presents continuous cell replacement. Although the constant enterocyte turnover is costly in terms of energy and nutrient expenditures, it may be justified because it removes cells that might have been invaded by pathogens (Buddington et al., 1997). In grass carp, enterocytes can remain on the villi for 15-20 days (Stroband \& Debets, 1978), but in Carassius auratus, cell replacement rate is much higher, with complete renewal of mucosal cells estimated to take approximately 6 days (Vickers, 1962). During food deprivation, fish reduce cell component turnover in order to save energy (Jobling, 1994). This can suggest that changes observed in the gut of traíra, as well as in other starved fishes, is a reflex of structure renewal rate modification, leading to gradual tissue degeneration.

A decrease in the number of epithelial cells could result from either a dcell proliferation rate reduction in the crypts of the intestine, or an increase extrusion rate of either old or dead cells (Hall \& Bellwood, 1995). Both would result in decreased mucosal fold heights and total mucosal surface area reduction. Likewise, decreased epithelial cell heights may result from a shortening of existing epithelial cells or through the production of shorter cells, resulting in mucosa thickness reduction (Hall \& Bellwood, 1995).

In this study, the number of pyloric caeca in starved traíra remained approximately constant. However, their length and thickness decreased in response to food deprivation. The size of caeca of starved Pseudopleuronectes americanus also decreased (McLesse \& Moon, 1989) and degenerated in salmon during spawning migration, when the species was deprived of food (Love, 1970). In traíra, changes in pyloric caeca occurred later than in the intestine. In general, the anterior portion of the intestine seemed to be less affected than the posterior portion. Gas \& Noaillac-Depeyre (1976) observed the persistence of microvilli in the proximal section of the intestine of carp (Cyprinus carpio). The microvilli, however, disappeared completely from the middle section after a 13-month starvation period.

Conversely, while intestine length of traíra remained reduced after refeeding, the thickness of pyloric caeca was recovered and overcompensation in the length of these structures was observed. The longer pyloric caeca presented by refed traíra after 240 days of starvation suggest an adaptation to enlarging the absorptive surface, thus compensating for intestine reduction. In carp, the renewal of the anterior part of the intestine was also quicker than that of the posterior part (Love, 1980).

Elliot (1972) found that the digestion rate of refed Salmo trutta presented no changes in fish previously starved for periods shorter than 7 days, but a reduced digestion rate was observed when fish 
were deprived of food for periods of longer than 10 days. Zavala-Camin (1996) related these data to digestive tract retraction and degeneration due to disuse.

In Macquaria ambigua food consumption occurred immediately in the refeeding period, which the authors attributed to epithelial regeneration (Collins \& Anderson, 1995). Similarly, the ready digestion of food by refed traíra indicates that, despite the observed changes, the digestive tract remained functional during food deprivation. However, it is not possible to affirm that digestion occurred at normal rates. Therefore, further studies are required.

Acknowledgements - We thank FAPESP for providing a PhD fellowship to Flavia S. Rios (Proc. 90/06737-3), field technician Nelson S. A. Matos for collecting the fish, and Tereza Costa for technical support.

\section{REFERENCES}

ANGELESCU, V. \& GNERI, F. S., 1949, Adaptaciones del aparato digestivo al régimen alimenticio en algunos peces del Río Uruguay y del Río de La Plata. Rev. Inst. Nac. Invest. Cienc. Nat., 1: 161-272.

BAEVERFJORD, G. \& KROGDAHL, Å., 1996, Development and regression of soybean meal induces enteritis in Atlantic salmon distal intestine. J. Fish Dis., 19: 375-387.

BARBIERI, G., PERET, A. C. \& VERANI, J. C., 1994, Notas sobre a adaptação do trato digestivo ao regime alimentar em espécies de peixes da região de São Carlos (SP). I. Quociente Intestinal. Rev. Brasil. Biol., 54: 62-69.

BISTONI, M. A. B., HARO, J. G. \& GUTIÉRREZ, M., 1995, Feeding of Hoplias malabaricus in the wetlands of Dulce River (Córdoba, Argentina). Hydrobiologia, 316: 103-107.

BUDDINGTON, R. K \& DIAMOND, J. M., 1986, Pyloric caeca of fish: a 'new' absorptive organ. Am. J. Physiol., 15: G65G67.

BUDDINGTON, R. K., KROGDHAL, A. \& BAKKEMcKELLEP, A. M., 1997, The intestines of carnivorous fish: structure and functions and the relations with diet. Acta Physiol. Scand., 161(suppl. 638): 67-80.

CARAMASCHI, E. M. P., 1979, Reprodução e alimentação de Hoplias malabaricus (Bloch, 1794) na represa do rio Pardo (Botucatu-SP) (Osteichthyes, Cypriniformes, Erythrinidae). MSc Thesis, Universidade Federal de São Carlos, Brasil, 144p.

COLLINS, A. L. \& ANDERSON, T. A., 1995, The regulation of endogenous energy stores during starvation and refeeding in the somatic tissues of the golden perch. J. Fish Biol., 47: 1004-1015.

DAWES, B., 1929, The histology of the alimentar tract of the plaice (Pleronnectes platessa). Q. J. Microsc. Sci., 73: 243274.
ECKMANN, R., 1985, Histopathological alterations in the intestine of whitefish (Coregonus sp.) larvae reared on zooplancton from Lake Constance. Dis. Aquat. Org., 1: 1117.

ELLIOT, J. M., 1972, Rates of gastric evacuation in brown trout, Salmo trutta L. Freshw. Biol., 2: 1-18.

EHRLICH, K. F., BLAXTER, J. H. S. \& PEMBERTON, R., 1976, Morphological and histological changes during the growth and starvation of herring and plaice larvae. Mar. Biol., 35: 105-118.

GAS, N. \& NOAILLAC-DEPEYRE, J., 1976, Studies on intestinal epithelium involution during prolonged fasting. J. Ultrast. Res., 56: 137-151.

GERKING, S. D., 1994, Feeding ecology of fish. Academic Press, San Diego, $415 \mathrm{p}$.

GUILlOU, A., CHOUBERT, G. \& DE LA NOUE, J., 1992, Absorption and blood clearance of labelled carotenoids 14C astaxanthin, $3 \mathrm{H}$ canthaxanthin, and $3 \mathrm{H}$ zeaxanthin in mature female rainbow trout Oncorhynchus mykiss. Comp. Biochem. Physiol., 103A: 301-306.

HALL, K. C. \& BELLWOOD, D. R., 1995, Histological effects of cyanide, stress and starvation on the intestinal mucosa of Pomacentrus coelestis, a marine aquarium fish species. J. Fish Biol., 47: 438-454.

IIDA, H. \& YAMAMOTO, T., 1984, Morphological studies of the goldfish hindgut mucosa in organ culture. Cell Tiss Res., 238: 523-528.

JANSSON, B. \& OLSSON, R., 1960, The cytology of caecal epithelial cells of Perca. Acta Zool., 41: 267-276.

JOBLING, M., 1994, Fish Bioenergetics. Chapman \& Hall, London, 309p.

KNÖPPEL, H. A., 1970, Food of central Amazonian fishes: contribution to nutrient-ecology of Amazonian rain-forest stream. Amazoniana, 2: 257-352.

KUBITZA, F., 1999, Nutrição e alimentação dos peixes cultivados. 3a ed., Fernando Kubitza, Jundiaí, 123p.

KUPERMAN, B. I. \& KUZ'MINA, V. V., 1994, The ultrastructure of intestinal epitelium in fishes with different types of feeding. J. Fish Biol., 44: 181-193.

LOVE, R. M., 1970, The chemical biology of fishes. Academic Press, London, v. I, 547p.

LOVE, R. M., 1980, The chemical biology of fishes. Academic Press, London, v. II, 943p.

LOWE-McCONNELL, R. H., 1975, Fish communities in tropical freshwaters: their distribution, ecology and evolution. Longman, London and New York, 337p.

MACHADO, C. R., GARÓFALO, M. A. R., ROSELINO, J. E S., KETTELHUT, I. C. \& MIGLIORINI, R. H., 1989, Effect of fasting on glucose turnover in carnivorous fish (Hoplias sp.). Am. J. Physiol., 256: R612-R615.

McLESSE, J. M. \& MOON, T. W., 1989, Seasonal changes in the intestinal mucosa of winter flounder, Pseudopleuronectes americanus (Walbaum) from Passamaquoddy Bay, New Brunswick. J. Fish Biol., 35: 381-393. 
MENIN, E. \& MIMURA, O. M., 1991, Anatomia funcional da cavidade bucofaringeana de Hoplias malabaricus (Bloch, 1794) (Characiformes, Erythrinidae). Rev. Ceres, 38: 240255.

NOAILLAC-DEPEYRE, J. \& GAS, N., 1974, Fat absorption by the enterocytes of the carp (Cyprinus carpio L.). Cell Tiss. Res., 155: 353-365.

NONOTTE, L., NONOTTE, G. \& LERAY, G., 1986, Morphological changes in the middle intestine of the rainbow trout, Salmo gairdneri, induced by a hyperosmotic environment. Cell Tiss. Res., 243: 619-628.

O'CONNELL, C. P., 1976, Histological criteria for diagnosing the starving conditions in early post yolk sac larvae of the northern anchovy, Engraulis mordax Girard. J. Exp. Mar. Biol. Ecol., 25: 285-312.

OSTOS GARRIDO, M. V., NUNEZ TORRES, M. V. \& ABAURREA EQUISOAIN, M. A., 1993, Lipid absorption by enterocytes of the rainbow trout Oncorhynchus mykiss. Diet-induced changes in the endomembranous system. Aquaculture, 110: 161-171.

PAIVA, M. P., 1974, Crescimento, alimentação e reprodução da traíra Hoplias malabaricus no Nordeste brasileiro. Editora da Universidade Federal do Ceará, Fortaleza, 216p.

PETERS, G., 1982, The effect of stress on the stomach of the European eel, Anguilla anguilla L. J. Fish Biol., 21: 497-512.

RIOS, F. S., KALININ, A. L. \& RANTIN, F. T., 2002, The effects of long-term food deprivation on respiration and haematology of the neotropical fish Hoplias malabaricus (Bloch). J. Fish Biol., 61: 86-95.

SEGNER, H., BURKHARDT, P., AVILA, E. M., JUARIO, J. V. \& STORCH, V., 1987, Nutrition-related histopathology of the intestine of milkfish Chanos chanos fry. Dis. Aquat. Org., 2: 99-107.
SOMASUNDARAM, B., KING, P. E. \& SHACKLEY, S. E., 1985, The effect of zinc on the ultrastructure of the posterior gut and pronephric ducts of the larva of Clupea harengus L. Comp. Biochem. Physiol., 81C: 29-37.

STROBAND, H. W. J. \& DEBETS, F. M. H., 1978, The ultrastructure and renewal of the intestinal epithelium of the juvenile grass carp Ctenopharyngodon idella. Cell Tiss. Res., 187: 181-200.

THEILACKER, G. H., 1978, Effect of starvation on the histological and morphological characteristics of jack mackerel, Trachurus symmetricus larvae. Fish. Bull. (US), 76: 403-414.

URIARTE, I. \& BALBONTÍN, F., 1987, Caracterización del estado de hambruna en las larvas de sardina Sardinops sagax musica (Pisces, Clupeiformes), mediante criterios morfométricos y histológicos. Rev.Biol. Mar. (Valparaíso), 23: 77-106.

VICKERS, T., 1962, A study of the intestinal epithelium of the goldfish Carassius auratus: its normal structure, the dynamics of cell replacement, and changes induced by salts of cobalt and manganese. Q. J. Microsc. Sci., 103: 93-110.

WILLIAMS, J. A. \& NICKOL, B. B., 1989, Histological structure of the intestine and pyloric caeca of the green sunfish, Leopomis cyanellus Rafinesque. J. Fish Biol., 35: 359-375.

YIN, M. C. \& BLAXTER, J. H. S., 1986, Morphological changes during growth and starvation of larval cod (Gadus morhua L.) and flounder (Platichthys flesus L.). J. Exp. Mar. Biol. Ecol., 104: 215-228.

ZAVALA-CAMIN, L. A., 1996, Introdução aos estudos sobre alimentação natural em peixes. EDUEM, Maringá, 129p. 